\title{
Methods of Forecasting and Management of Land Fund Diversification in Local Areas
}

\author{
Altiev Abdurashid Sultanovich, Mahsudov Muhammadbek Dilshodbek Ugli
}

\begin{abstract}
This article focuses on the allocation of land resources to meet the socio-economic needs, diversification of land relations, the need for full and effective use of land resources. Diversification of land resources requires improvement of land allocation and redistribution. In improving the methods of land resource diversification, it is necessary to abandon old-fashioned methods.

The growing number of people every year makes it necessary to prepare for the future. Regional development is primarily planned and prepared for the future. These processes should have high accuracy in predicting processes. It is crucial to ensure that all land categories are used efficiently, ensuring diversification of the lands, in a rapidly changing, diverse manner. Also important is the issue of socioeconomic protection of the population, creation of new jobs and the privatization of land use rights for the creation of comfortable life.

Scientific research work is aimed at regulating land relations in the context of land restraint, identifying existing problems in meeting the needs of the society and the economy, drawing up a general scheme of land use in the district to predict the full and effective use of land, distribution of land resources between sectors and social spheres, distribution issues.
\end{abstract}

Keywords : land use, land management, land allocation, reserve land, land redistribution, regulation, diversification, planning.

\section{INTRODUCTION}

In the conditions of market relations, it is important to predict the development of the real sector of the economy, to predict, predict the future on a scientific basis, based on the laws, trends in the development of this society and the economy, as well as to establish program actions that embody the goals and objectives of the overall development of society. Forecasting the national real sector economy is of great importance in the theory and practice of drawing up and managing a promising program in the regulation of the trends of the world economy, the priority direction of the country in the development of the industry.

"Forecasting" in the Real sector is the definition of the prospect of real sectors in the national economy, another stage of the process of regulation of the sector, or part of the development of a program of prospects for the development of the real sector of the country. Forecasting is the process of

Revised Manuscript Received on October 15, 2019.

* Correspondence Author

Altiev Abdurashid Sultanovich, doctor of science in economics., docent., Tashkent Institute of Irrigation and Agricultural Mechanization Engineers

Mahsudov Muhammadbek Dilshodbek ugli - master student, Tashkent Institute of Irrigation and Agricultural Mechanization Engineers. developing a future perspective forecast of development, which is a set of ideas based on the ilrni about the state of the subject under study after a certain period of time, the ways and duration of its alternative development. The forecast has the characteristics of probability, multiple options and alternatives. Planning is the process of scientific justification of the means by which development is achieved, the definition of priorities and ways of achieving them. In practice, it is carried out by developing plans. The plan is a system of indicators that show the solution of economic and social issues and a document that makes the whole spectrum of various activities viable. It shows the purpose of the plan, priority areas, sources of supply, execution procedure and duration. The processes of forecasting and planning complement each other.

In economics and practice, various methods of planning have been developed and introduced. In particular, many of them direktiv, indicative, strategic, tactical planning methods are used.

Directive planning (mandatory, strictly controlled, must be executed) - implies the delivery of a plan assignment from the center to the entire structure of the economy, which is mandatory for execution. The plans are approved, first of all, taking into account the general needs and have the power of law. This planning is inherent in a centralized-planned economy, and in a mixed economic management system it is used only for emergency situations and for rapid structural restructuring in an economy during periods of existence.

In inductive planning, the needs of the state and the entrepreneur are taken into account, it is carried out on the basis of the issuance of proposals. At the same time, there is a management system that directly and indirectly affects the qoi of the state. These are: various system of benefits, licensing, quotas, subsidies, dotations, etc. In indicative planning, macroeconomic indicators are used in the management of the economy as indicators. These are gross domestic product, retail turnover, employment, the real amount of wages. The component of indicative planning is the implementation of priority directions of economic development through the mechanism of consensus (mutual agreement) with major financial and industrial groups, trade unions, union of entrepreneurs and other community organizations.

Strategic planning is the process of identifying goals that are planned for a long period of time, proving its priorities and ensuring its implementation.

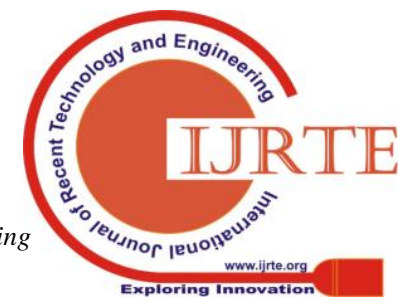


Its main goal is to create a sufficient number of conditions for the successful development of the country in the future. In its development, technological, economic, competitive, social, international, market and political factors are taken into account [15].

In strategic planning, directive, inductive and tactical planning methods are used in the implementation of the objectives set.

Tactical planning is a kind of planning, designed for 1-2 years, in which the main functional areas of production programs are carried out, material and technical support, payment of wages, volume of sales of products, costs, finance, social planning. A tactical plan is a set of indicators that indicate the production, economic and social activities of the enterprise, aimed at carrying out the tasks of the strategic plan of the enterprise through the use of available resources with savings.

As the main subjects of socio-economic forecasting, demographic, economic, social sphere, ecology and indicators of scientific and technical progress are manifested. The development of the economy, historically, determines the number of inhabitants, the availability of resources and the level of technology.

The method of economic forecasting is a dialectical method in which future results can be seen on the basis of factors and views being studied, looking at the objects being sought. It is carried out on the basis of general scientific methods and approaches to research, as well as specific methods based on scientific forecasting of economic outlook.

The historical approach is to consider the interaction of each event with its historical structure. The past is due to the interconnectedness of the present and the future, the future exists as it is now. Therefore, forecasting is the law and tendency of the present to go beyond it, and on its basis is associated with the development of an already non-existent model of the future. The link between the existence of different historical formations of the same appearance indicates that the current appearance of the sought-after object is the result of its previous development. The logical invention of such an approach is aksi the historical character of Social Development [2].

Komplex approach - includes consideration of events and their attachment and resistance.

The systematic approach implies the study of the passage of processes that can be voluminous and qualitative in complex economic systems. They play a big role in economic forecasting. Each view of the event can be taken as a system. This means that they consist of a number of interrelated functions, interrelated parts that provide an advantage. Knowing this advantage and functionality, it is possible to predict the action of the subject under study.

Structural approach-research in forecasting objects plays a big role. In the structural approach, the object of research is considered in the context of the elements contained in it and their mutual action. This makes it possible to imagine the subject under study.

The structural-structural approach implies on the one hand to look at the system as a dynamically developing whole, on the other hand, it is the division of the system into structural elements in the mutual movement, because in reality every structural element has the same effect on the whole system as it does on all other elements. With this, the opportunity arises to open the legitimacy of the connection of system elements [10].

Land management is an important part of the economy. In order to develop the concept of development of a state territory, it is necessary to create modern methods of land management on the basis of the district and suburbs of the lower boundary. The use of land resources should always be monitored. The need to predetermine the use of land resources, and the need to allocate land to the economy and social sectors, to organize the effective use of land resources, and to diversify the use of land resources. In the development of methods for diversifying land use diversity, it is necessary to step through the steps of analyzing, determining and forecasting the existing land distribution between the land fund. The experience of developed countries shows that one of the main factors in the development of the economy is the rational use of natural resources.

Regions and districts of the Republic of Uzbekistan have different regions according to their location, climate, relief and soil conditions. In such a case, it is based on accurate, scientifically grounded estimation of the agricultural sectors in these provinces and districts, the main crops planting perspective crops and on this basis further development of agriculture is based on unconditional information.

Although the organizational aspects of the use of land resources are relatively stable, however, their legal dimensions have some deficiencies. In my view, these shortcomings are largely due to the fact that the contract for the use of land-use practice has a lot to do with. Under these circumstances, the introduction of new resource-saving technologies in all sectors of the economy to minimize land allocation in areas where land is needed, to identify land degradation and to improve ecological conditions for land use planning, planning and economic growth. production. One of the main goals of land resources management and management is to achieve a new level of distribution of the state land fund based on land categories and types of land, based on the creation of a resource-saving system for land users. As you know, this complex process needs a complex approach to land use, not with the use of some private or local measures, but in the use and management of land resources. But developing complex measures does not completely solve the problem. Therefore, it is necessary to create scientific-methodological foundations of modern integrated systems of land use and management, which provide targeted development of land use, planning and economic development. A positive outcome of the use and management of land resources is measured by the sustainability of the social, economic and environmental situation in the area and the improvement of these indicators [3]. 
Under market conditions, the use and management of land resources must be implemented in accordance with market mechanisms. Because the provision of the population's nutritional and industrial needs for raw materials is largely dependent on the outcome of management and, in particular, on the improved level of use and management of land resources. Methods of management should be governed by law. Land categories and land types are distributed in the districts, cities, towns, regions and in different proportions. In such circumstances, it is necessary to take into account the administrative and territorial characteristics of land management and land management issues [12].

In this process, the physical condition of the use of land resources should be determined. A comparative analysis of the effectiveness of the various options is conducted, and the proposed option is legally feasible, financially feasible, and then develops proposals for the decisions of the local government or the local authorities. Below are the types of space available in society. The further development of the process of forecasting the diversification of land use and the expansion of its economic content are of great socio-economic importance today, because in the conditions of the market economy, the prospects for land allocation opportunities will be further enhanced on the basis of the results of prgonosis. This, in addition to ensuring the full use of the land fund, serves to prevent their idle and inefficient use. By improving the methods of forecasting the diversification of the district land fund, production in the district, creating a new type of market infrastructure, increasing the efficiency of the use of the land fund, ensuring employment, ensuring the balance of demand and supply for land and other positive results will be achieved. Below are the types of land use efficiency in the targeted land.

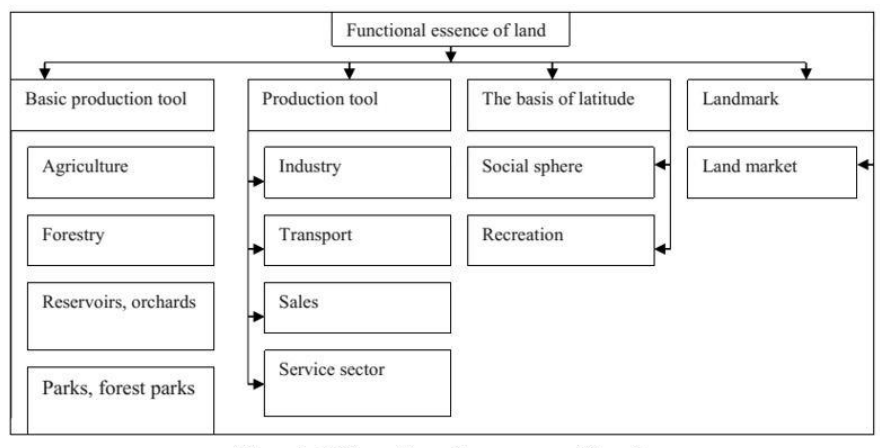

Graph 1.Functional essence of land

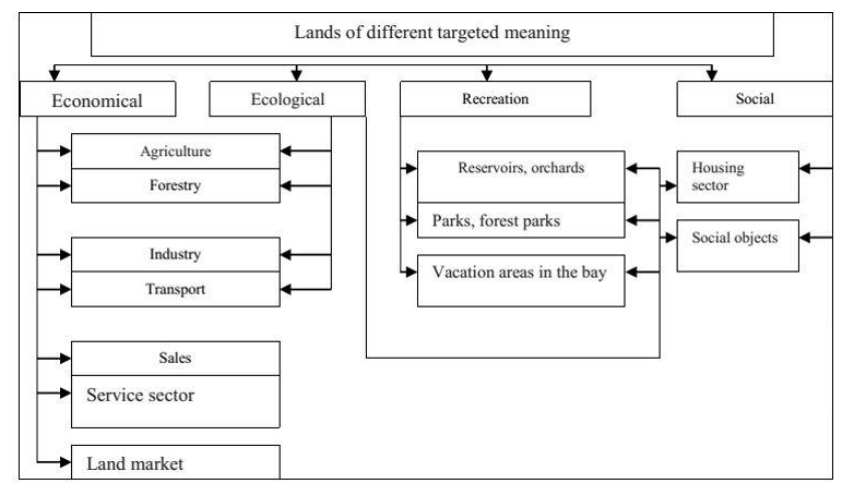

Graph 2. Lands of different targeted meaning
The purpose of the scientific work is to improve the methods of forecasting the use of land in the district in the conditions of diversification of demand for land resources and land use.

The relevance of the topic is the regulation of land relations in conditions of limited availability of land resources, the satisfaction of the needs of society and the economy to them, the continuous redistribution of land resources between economic sectors and social spheres. Today, the distribution of Land Fund does not fully correspond to the needs of society and the economy. Because the distribution of the Land Fund is not developed precisely, in conditions of increasing population from year to year, there is no full-fledged land accounting. In particular, in the conditions of the market economy, the lack of full use of available resources, the share of reserve land in the Land Fund is increasing from year to year, the population's need for land use, land demand, private property is increasing from year to year and so on. In such cases, as a result of carrying out research on the content of distribution and redistribution of Land Fund and improvement of its validity, the development of scientific-practical proposals and recommendations is pressing [14].

Research methods - statistical, monographic, economic-mathematical, analysis and synthesis, comparative and logical concomitant and other methods are widely used in carrying out the research.

The most important of these is the legal norms related to land resources, which are important. In this regard, one of the main obstacles to the effectiveness and development of land reform is to focus on the imperfections of competent jurisdictions on land ownership.

Diversification comes from the Latin term "diversificatio", which means "change", "diverse development". Diversification is the expansion and renewal of the types of products and services of enterprises [16].

The development of these indicators is based on the classification of land and the soil characteristics based on their natural condition and their internal characteristics. The land cadastre for the development of these indicators provides the basis for calculating the quantity and quality of irrigated, saline lands. Land use planning is usually used for indirect planning, primarily for forecasting, including the master plan for new acquisition, the general scheme of use of natural fodder, land cadastre data through the district and regional schemes of land use. Their implementation will ultimately serve as a basis for identifying indicators in the national document in accordance with the general scheme of land use in the future. It can be said that land relations are divided into four types:

1) property right to land;

2) public administration of land;

3) land use;

4) on land law enforcement. 
Land-use relationships in the field of land use are also derived from land-related legal relations. Legal relationships arising from land use are divided into two types: direct use of the land, that is, the use of land and indirect access to land, ie the right of land users, land owners and lessees to land is not liable to land ownership. The proprietor or his agents shall give the right to use land in any legal form to others (legal or natural persons). Land use right may be primary or secondary, without the right of ownership. Legal relations in the field of public administration, as well as in the field of protection of the rights and interests of landowners and owners, users and tenants, are subdivided into material and procedural questions. Implementation of procedural legal relationships between material rights relations between the state-owned entity and the state body authorized to grant land parcels constitutes a new material and legal basis for the use of a land parcel.

As the population increases, their needs will increase. In the first place, the need for food is taken into account in promising projects. Also, the population should be busy with self-sufficiency. In order to regulate the diversification of the use of resources, it is necessary to create long-term schemes for each region and region. The scientific technical concept of the general scheme is that we understand the general aspects of the use of land resources in the future. The amount of land fund and its qualitative variation occurs when:

- when placing production forces;

- development of production capacities;

- when implementing environmental protection activities;

- when carrying out activities on land improvement.

Diversification is diversificatio of Latin word means "'change',, 'diversity development', Diversification is achieved through high productivity and high profitability, elimination of bankruptcy and other purposes. In the past, access to specialized industries in other industries, primarily in highly profitable industries, has expanded their spheres of economic activity. Diversification in the countries of the world began to develop in mid-50's in the mid-20th century. Initially, diversification in the United States, Japan, and Western European countries will occur in industry, transport, construction, and finance. Therefore, the diversification movement is determined by socio-economic factors of these countries, as well as common factors (scientific-technical revolution, high profit struggle, competitive struggle, technical development, etc.) that belong to other states. Diversification of Land resources use:

- direct allocation of the land fund of the existing land in order to achieve high efficiency;

- changing the land fund category;

- it is necessary to allocate or allocate a huge economic and social benefit.

Diversification is carried out in production with high productivity, economic benefits, elimination of bankruptcy and other goals. Previously, firms specializing in one area (industry, agriculture, transport, finance, etc.) expanded their economic activities and access to services, primarily in high-income sectors. Diversification will lead to the creation

of a broad, but technologically unconnected complex (for example, the agro-industrial complex, the forest industry), which produces, produces various types of goods, services the economy and development sectors and is called production diversification. In addition, there is a diversification scheme for loans (in which capital funds are distributed among various items to reduce risk and increase profits). Economic entities need to build long-term plans that will ensure sustainable development, however, for this, enterprises should look for alternatives to the existing specialization of production. In this regard, there is a need for a strategic approach to the management of agricultural enterprises. Enterprises are faced with the task of finding development strategies that allow them to solve a number of economic problems of agriculture, and consequently, social problems and, above all, an increase in the level of employment, and hence the standard of living in the countryside. One of the strategic alternatives of long-term planning is diversification [17].

In the economic literature there is a large variety of definitions of diversification. But the difficulty lies in the fact that diversification is such a concept that cannot be given an unambiguous definition. "I don't know of a more complex management problem than diversification ... although as an abstract idea, it doesn't represent anything complicated. The results of this plan can be so varied ...". These words of Joseph T. Wright are taken as an epigraph to the chapter "Diversification and internationalization", which was first translated into Russian by "New Corporate Strategy" by Igor Ansoff, the originator of strategic planning and management. To the well-known scientist I. Ansoff, to say: diversification is a term applied to the process of redistributing resources that exist in this enterprise in other areas of activity that differ significantly from the previous ones. Moreover, this process concerns, first of all, the transition to new technologies, markets and industries, to which the company had nothing to do before; in addition, the products of the enterprise itself must also be completely new. I. Ansoff focuses on new firms entering new markets with new products. F.E. Udalov and O.F. Udalov in monographs "Management and Conversion: Problems and Prospects" give the following definition: "Production diversification means its focus on multi-product output. Diversification is the expansion of the product range or, in other words, "mine for a single product". Based on a number of definitions, we denote diversification as a process of enhancing the economic efficiency of an enterprise and reducing financial risks, based on the development of new industries and expanding its market share.

The idea of diversification has a long history. The first theoretical developments on the problems of diversification appeared in the $20 \mathrm{~s}$ of XX century. The economic prerequisites for the development of production diversification were the concentration of production and the centralization of capital within the industry. 
This led to a clear specialization of production and the creation of "clean industries". The most tangible development of diversification was obtained in the mid-50s, when for the first time the relative exhaustion of domestic sources of growth in production efficiency and a drop in the rate of profit on capital invested in traditional production manifested itself. Diversification was a trend in connection with the concept of corporate development in the late 60 s and early 70s. To avoid the risk of capital investments in certain industries, the largest concern sought to expand the range of goods produced, to find new forms of investment, to penetrate into industries that have no direct connection with the main field of their activities. At the moment, diversification has become the most common form of concentration of capital. Today, diversification is considered an element of strategic management, which arose due to satisfied consumer demand and the emergence of the need for enterprises to maintain their place on the market by creating additional advantages for them [19].

\section{METHODS}

Diversification has pushed aside the effect of mass production of homogeneous products, leading to the realization of growth strategies due to the "effect of diversity". The essence of the effect of diversity is that the production of many types of products in one large enterprise is more profitable than the production of the same types of products in small specialized enterprises.

However, when deciding on the diversion of agricultural enterprises, a number of features of agriculture should be taken into account:

- discrepancy of the working period with the production period (seasonality);

- the intertwining of biological and economic processes;

- dispersed territory;

- the land acts as a means of production.

Diversification due to the development of other areas of activity will reduce seasonality and the negative consequences associated with it, arising from agricultural enterprises. In most enterprises, the development of new industries, along with existing ones, will provide a more rational use of all available resources, which in turn will lead to an increase in the economic efficiency of the enterprise as a whole. This is especially true for farms located in remote areas, which, due to their specialization, do not use the available land, and because of their remoteness from other farms are not able to rent them out.

Thus, the strategic development of the agro-industrial complex, based on the diversification of the activities of agricultural enterprises, will most fully and rationally use the natural and production potential, expand the range and increase the production volumes of the agro-industrial complex. The strategy of diversifying the activities of an agricultural enterprise will aim it at the creation and stabilization of an efficient economy that satisfies the needs of the external and internal socio-economic environment [11].

In the agricultural context, diversification can be seen as the redistribution of some farm production resources, such as land, capital, agricultural equipment and agricultural land, to other farmers and, especially in richer countries, non-agricultural activities, such as restaurants and shops. There are many factors leading to decisions on diversification, but they include; reducing risk, responding to changing consumer demands or changing public policy, responding to external shocks and, more recently, as a result of climate change.

Diversification strategy refers to the development of new product markets, the release of new products, the provision of new types of services. A diversification strategy usually involves not only introducing diversity into product groups or service groups, but also extending the business of the enterprise to new ones that do not overlap with those already developed by the business sphere. The diversification strategy is designed to develop new types of products while entering new product markets [11].

As the population increases, their needs will increase. In the first place, the need for food is taken into account in promising projects. Also, the population should be busy working to ensure that they are financially self-sufficient. In order to regulate the diversification of land use, it is necessary to create long-term schemes for each region and region. Diversification of Land Resources Use:

- direct allocation of the land fund of the existing land in order to achieve high efficiency;

-changing the land fund category;

- it is necessary to allocate or allocate a huge economic and social benefit.

In order to diversify the use of land resources, plans for future use should be fully developed. Key areas of perspective use of land resources are based on scientific and technical materials and should include the following:

1.Responding to the Earth Fund, the procedure of land allocation for landowners and land users, their dynamics, zoning of the land fund.

2. Land category analysis and evaluation of land use.

3. Calculation of perspective areas in the national economy.

4. Transfer of spare land to agricultural business turnover.

5. Increased intensive use of land;

6. Transformation, increase of soil fertility, improvement of land ownership.

7. Protection and improvement of land resources, improvement of land reclamation, erosion, protection of territories and organization of cultural landscape.

8. Territorial problems of rational use and protection of lands.

9. Improving the effectiveness of the tasks.

For the development of the economy, all sectors need to be developed in the environment. It is necessary to consider the use of unused lands and agricultural land.

There are several ways to further use the land resources:

- expert evaluation method;

- learning dynamic rows;

- direct forecasting based on extrapolation or statistical mathematical indicators;

- standard-target comparison methods and others. 
In order to regulate the diversification of land use in the Altyaryk district of Ferghana region, which is a research object, it is desirable to develop and implement the following:

- a set of short-term measures;

- a set of medium-term measures.

Development and implementation of a set of measures on a district level:

-First of all, these measures will increase diversification of the use of land resources in the region. It also provides centralized effect;

-Secondly, it provides the introduction of uniform rules for all land users.

It is therefore desirable to take the following measures to increase the diversification of the use of land resources based on the results;

-targeted orientation by studying the level of productivity, increasing from year to year, based on the results of decades;

-elimination of irrational use of lands of the Forest Fund, development and implementation of measures, such as the production of landscapes, selection works, landscape crops, various economic benefits from the forest lands;

-consideration of privatization or rent issues, in particular cases and circumstances, of dehkans and farms, in general, for some categories of land;

-development of offers on issues of use, realization, transfer to the competent authorities of the right to lease;

-strengthening the link between ownership of industrial property rights. Wide implementation of the incentive system's capacities;

-development and application of practical programs for the introduction of irrigation technologies;

-enhancement of its efficiency by improving meliorative conditions of the land;

-ensure the implementation and control of engineering-related activities based on scientifically-based recommendations.

First of all, the Altyaryk district needs an assessment of land demand in the economic fields over the next 10 years, as shown in Table 1. Then, based on these results, a set of measures will be developed [18].

\section{ANALYSIS AND RESULTS}

The district's diversification of land resources, the rational and efficient use of the land fund, and especially the development of a market economy, are now largely dependent on the national economy. Thus, distribution and redistribution of separate categories of land between land ownership, land users, land owners or all types of land, land users or different types of land are legal processes and it occurs on a regular basis. This process is regulated by the state as the main property of the land fund and regulated by the executive authorities of the state, taking into account the priority of agricultural issues. Land acquisition and redistribution are under constant government control [1].

Depending on the purpose of granting land parcels, they may be subdivided into certain categories of single land fund or transferred to another category. The development of industry, transport, agriculture and other sectors requires the permanent allocation of land plots to the needs of the national economy. As the Republic is limited to a single land fund, its distribution and redistribution are naturally carried out on a regular basis.

Table 1:Land allocation of Altyaryk district by category of land fund

\begin{tabular}{|l|l|l|l|l|l|}
\hline $\begin{array}{l}\text { Order } \\
\text { number }\end{array}$ & Land fund categories & $\begin{array}{l}\mathbf{2 0 0 8} \\
\mathbf{\%} \text { share }\end{array}$ & $\begin{array}{l}\mathbf{2 0 1 1} \\
\mathbf{\%} \text { share }\end{array}$ & $\begin{array}{l}\mathbf{2 0 1 4} \\
\mathbf{\%} \text { share }\end{array}$ & $\begin{array}{l}\mathbf{2 0 1 8} \\
\mathbf{\%} \text { share }\end{array}$ \\
\hline 1 & Agricultural land & $51,57 \%$ & $50,63 \%$ & $48,85 \%$ & $47.75 \%$ \\
\hline 2 & $\begin{array}{l}\text { Lands of settlements } \\
\text { (residential areas) }\end{array}$ & $11,86 \%$ & $11,86 \%$ & $11,87 \%$ & $11.88 \%$ \\
\hline 3 & $\begin{array}{l}\text { Areas of industry, transport, } \\
\text { communication, defence and } \\
\text { other purposes }\end{array}$ & $6,90 \%$ & $6,93 \%$ & $6,94 \%$ & $6.95 \%$ \\
\hline 4 & $\begin{array}{l}\text { Lands for nature conservation, } \\
\text { health and recreational purposes }\end{array}$ & $0,14 \%$ & $0,15 \%$ & $0,15 \%$ & $0.16 \%$ \\
\hline 5 & $\begin{array}{l}\text { Lands of historical and cultural } \\
\text { heritage }\end{array}$ & $0,01 \%$ & $0,01 \%$ & $0,02 \%$ & $0.02 \%$ \\
\hline 6 & Lands of the forest fund & $1,29 \%$ & $1,31 \%$ & $1,33 \%$ & $1.33 \%$ \\
\hline 7 & Land of water fund & $4,4 \%$ & $4,42 \%$ & $4,44 \%$ & $4.44 \%$ \\
\hline 8 & Reserve land & $23,83 \%$ & $24,69 \%$ & $26,4 \%$ & $27.47 \%$ \\
\hline Total & & $100 \%$ & $100 \%$ & $100 \%$ & $100 \%$ \\
\hline
\end{tabular}

It should be noted that the distribution and redistribution of the single land fund is a continuous process. The constant development of industry, transportation, agriculture, cities and other residential areas necessitates land allocation for them. In the above-mentioned sectors, natural resources are restricted for the use of land plots. Therefore, it is necessary to redistribute land allotment so that different sectors of the economy need land parcels [4].

The results of the agro-economic zoning of the territory are taken as the basis for redistribution of lands. Sectors (agriculture and forestry, urban, industrial and water economy, construction, nature protection, etc.), taking into account natural (relational, soil, subsoil, vegetation, water resources and so forth) and socio- is determined. Complete or partial use of the results of agroecological zoning is determined taking into account the expected socio-economic conditions.

This situation requires accurate allocation of the ground areas, particularly the separate administrative areas. It is important to allocate reasonable land allocation to key users, landlords, tenants, and so on, in the implementation of the use of the administrative land, in line with the current market relations of the sectors of the economy. The allocation or redistribution of the land fund should be carried out on the basis of the requirements of its economy and, first and foremost, the interests of the state as the land is the property of the state, the common good. The correct use of this property, the proper distribution among the sectors will be the key to the development of the economy.

Land allocation is usually carried out by land management organizations. Land allocation works are carried out by architectural and construction organizations. Land allocation is a special document. Along with allocation of land in the inter-economic land tenure, the reverse movement of land is also the removal of land parcels. Land retreat is a movement and a right to land redistribution aimed at reducing land users' rights or restricting them. Registration of land for public and private purposes is carried out on the basis of special resolutions adopted by the competent authorities of the state. 
This decision may also occur in the form of a joint resolution on withdrawal of land and transfer of new land to users. In addition, some land parcels may be allocated for state and public needs. This is especially true for many people. In this case, it is necessary to determine the amount of damage and lost profits of the enterprises, which were allocated in the inter-farm land, and to compensate for these damages in the prescribed manner [5].

Land-based arrangement of inter-sectoral allocation of land fund. Realization of the inter-sectoral allocation of land fund is becoming one of the most important practical measures in the conditions of the current market relations, as in today's conditions it is necessary to allocate land for various enterprises, institutions and organizations, entrepreneurs and establish their activity based on the main interests of the state is one of the most important issues.

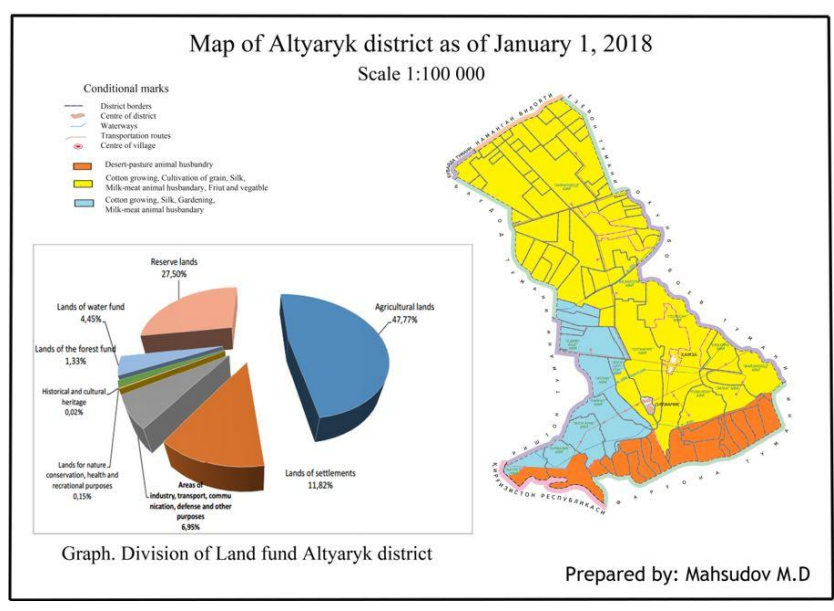

Graph 3. Land use change Altyaryk district

Depending on these requirements, the state will try to keep land allocation and redistribution more than once. These actions of the state are foreseen for allocation of land and, on the contrary, the withdrawal of land [6]. Land allocation is one of the main technical measures to be taken by land acquisition. In the inter-governmental structure of land allocation of land includes the following works:

- preparation and receipt of the decision of bodies of the state power on allocation of land;

- separation of land from the place of worship;

- legal registration of the land plot for use or ownership.

Land allocation is a complex process in which the boundaries and forms of the land parcel are determined. This work consists of the following components:

- study the boundaries of the land parcel and determine the forms on the ground;

- fixing the boundaries of land plots;

- drawing up of plot forms of parcels;

- drawing up of drawings of various water pipes, sewerage systems, electrical and telephone cables, high voltage power lines and other structures on and under the parcel of land plots.

Land allocation is usually carried out by land management organizations. Land allocation works are carried out by architectural and construction organizations. Land allocation is a special document. Along with allocation of land in the inter-economic land tenure, the reverse movement of land is also the removal of land parcels. Land retreat is a movement and a right to land redistribution aimed at reducing land users' rights or restricting them. This decision may also occur in the form of a joint resolution on withdrawal of land and transfer of new land to users. In addition, some land parcels may be allocated for state and public needs. This is especially true for many people. In this case, it is necessary to determine the amount of damage and lost profits of the enterprises, which were allocated in the inter-farm land, and to compensate for these damages in the prescribed manner.

As it is known, the lack of opportunities to expand the amount of land fund is constantly improving the social, economic and ecological significance of the land, as the industry has been growing from year to year [9]. Indeed, it is expedient to take into account market relations, taking into account the importance of society's production, strictly adhering to new economic relations. Under these conditions, the use of land in legal and institutional ways has become complicated. Especially important is the coverage of losses, losses and loss of profits of enterprises, institutions and organizations in the distribution and redistribution of land. Determination of losses and loss of profits during inter-farm land surveys, related to land allocation and redistribution, is based on the quality of land. Thus, the role and place of land management, in particular, inter-farm land management, is one of the major measures to improve land acquisition and redistribution.

Improve land allotment based on planning and use of district districts. In the context of major reforms carried out in the country, the demand for land, water and labor resources has increased, and the requirements for the specialization and modernization of agriculture are changing.

Particular attention is given to long-term forecasts for the development and deployment of productive forces in such a long-term implementation of land acquisition. Today, the main direction of using land resources is the country's economic reforms and market relations. Therefore, long-term planning of use of land resources in the further development of the country's economy, including agriculture, should be expanded [7].

It is well known that long-term forecasting and planning of land use, in particular the use of land resources, is made on the basis of commonly accepted methods and methods, ie on the basis of district area planning or schemes of urban planning. These documents, along with all the issues, will determine the areas of prospective distribution of cross-sectional areas and the intersectoral distribution. Based on their scale, prediction is into divided:

- microeconomic and predictable content;

- forecasts on the development of economic sectors;

- networked and scheduled forecasts; 
- predictions of separate production units of production units of the economic system of the primary system.

\section{DISCUSSIONS}

Since the concept of diversification is an economic concept, it is necessary to prioritize the land use prioritizing step-by-step implementation of the privatization process to establish a high-precision mechanism for calculating the economic value of land. The feature of the land as a key tool of agriculture is its productivity. The soil's ability to provide nutrients and moisture to plants is called soil fertility. Natural productivity is created by the nature itself. It will appear and develop under the influence of climate, plants, the relief of the earth, and the rocks in the process of long-term soil formation. It is characterized by physical, chemical and biological properties of soil. But based on natural fertility, the real quality of the land can not be estimated. In the soil, there may indeed be a great deal of nutrients, but for various reasons (moisture, light, etc.), they may be in the form of absorbing or insufficiently absorbing plants [8]. Artificial productivity is the result of the combination of human labor on land plots that have natural productivity. In other words, land plots with natural fertility are a subject of work for human activity. Potential or actual productivity is the ability of the soil to meet the demand for nutrients, taking into account natural, climatic and other factors. The main task of a human being is to manage this process, prevent the soil from sinking, and allow the nutrients to absorb the plants.

The limited land area, the diversity of soils, and the ever-increasing demand for agricultural products require the use of qualitative and unpopular land. This, in turn, is achieved by increasing the amount of capital investment and thus achieving a certain potential productivity. In this regard, the economic productivity of the soil will arise. Economic productivity is understood as a true expression of soil fertility and is characterized by the level of productivity of cultivated agriculture. The economic productivity of the soil is dependent on the amount of capital expenditures, the level of development of production forces and production associations, the processing of products, sales, etc. Economic productivity is subdivided into absolute and relative productivity [20].

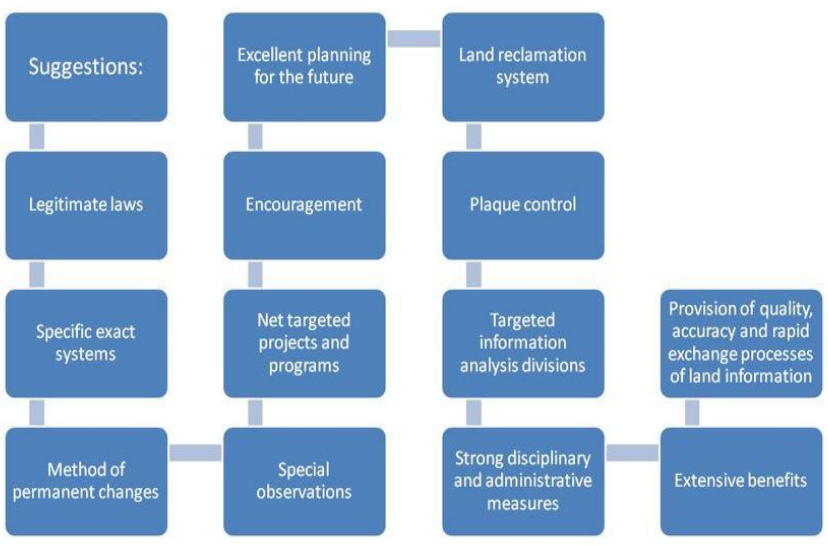

Figure 1. Suggestions

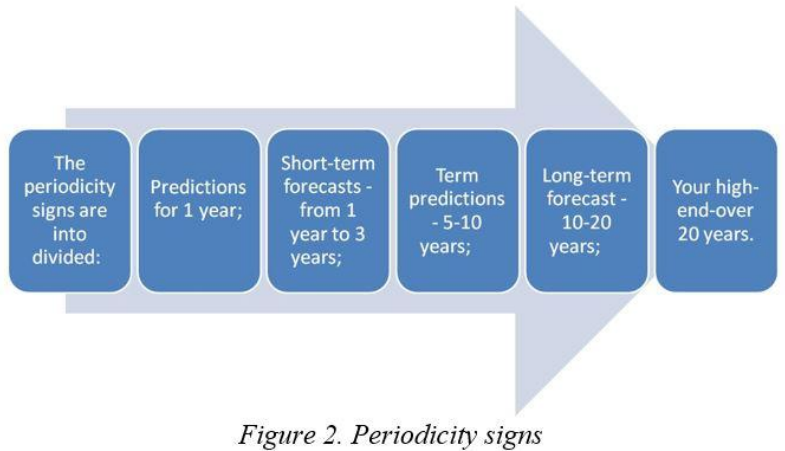

Absolute is expressed by the quantity of products grown under certain conditions and is characterized by the productivity indicator of a given area of land. The relative differential is characterized by the productivity of land plots and is characterized by the amount of products that are paid for certain expenses. In order to determine the extent of these fertility, there is a need to undertake land surveys, such as land degradation and land degradation.

\section{CONCLUSION}

Administrative datasets, such as "district general scheme," are a long-term forecasting document that allows predicting and distributing district districts 15-20 years ago. In addition to long-term forecasting of land use, planning is also crucial. That is why all the planning works are compiled and approved on the basis of the documentation, the use of land, the improvement of its cross-sectoral distribution, and the identification of land resources requirements for the sectors of the economy [13].

It is important to note, however, that proper allocation and redistribution of land allocation in the system of these measures is important because it has a distinctive feature in land use management and defines public policy for long-term use of land resources. In this context, the planning and planning documentation developed and implemented in the district will enable the region to carry out long-term distribution of natural-economic zoning of the region and regional zoning based on natural, socio-economic and ecological conditions of the region will give.

In view of this, we note that the main areas of perspective use of districts for research:

-improving land use and distribution in economic sectors;

- improvement of irrigation systems and irrigation systems;

- improving the quality and reclamation of land and their protection;

- rational organization of settlements and construction;

- introduction of market principles in land-water relations.

The growing demand for the district's economy, its productive forces, and its territorial development require objectively the development of sustainable distribution and use of land resources in the economic sectors. This allocation is not feasible due to land degradation, especially in the city. Expansion of populations is often provided by allocation of agricultural lands. 
In such cases, high quality irrigated lands are included in such areas. Replacement of these lands is mainly due to poor agricultural land. Converting them to highly productive areas requires considerable costs and time. Therefore, the use of long-term forecasts and plans for the use of land plots will be a positive influence in the area of land allocation and redistribution.

\section{REFERENCES}

[1] Anna KołodzieJczak, Tomasz Kossowski. Diversification of farming systems in Poland in the years 2006-2009. Quaestiones geographicae $30(2) \cdot 2011$.

[2] Babajanov A.R., Mahsudov M.D. Diversification of land fund in the district. Monograph. LAP Lambert Academic Publishing, 2019. -P. 44-46.

[3] Altiev A.S. The economic mechanism of liberalizing the land use system: monograph. - Tashkent: Fan, 2009. -P. 220-224.

[4] Brenda B. Lin. Resilience in Agriculture through Crop Diversification: Adaptive Management for Environmental Change. BioScience, Volume 61, Issue 3, 1 March 2011, -P. 183-185, https://doi.org/10.1525/bio.2011.61.3.4.

[5] Decree of the President of the Republic of Uzbekistan "On Measures for Implementation of the Diversification and Modernization of Agriculture Project" with the participation of the International Fund for Agricultural Development, November 20, 2018, PD- 4021.

[6] Dr. Siti Balkis., Dr. Ndan Imang., Mursidah, MP. Assessment of Land Use Changes and Implication to Diversification of Income Sources and Environment (Case Study at two Indigenous Dayak Ethnics in Miau Baru and Pampang Village). International Journal of Humanities and Social Science Vol. 8 • No. 7 • July 2018. -P. 22-23. doi:10.30845/iihss.v8n7y12..

[7] Evelyn Brister \& Elizabeth N. Hane (2013): Diversification of Land Management Goals and Strategies in Response to Climate Change, Ethics, Policy \& Environment, 16:1, 26-28. DOI: 10.1080/21550085.2013.768387.

[8] Enemark S., Williamson I., Wallace J. Building Modern Land Administration Systems in Developed Economies. SPATIAL SCIENCE Vol.50, No. 2, December 2005. -P. 56-57.

[9] Jakub Horák., Jan Materna., Josef P. Halda., Strahinja Mladenović., Petr Bogusch., Pavel Pech. Biodiversity in remnants of natural mountain forests under conservation-oriented management. SCientifiC REPORTS (2019) 9:89 | DOI:10.1038/s41598-018-35448-7

[10] Khasanov R., Asatullaev H., Suvonkulov A., Khakimov H. Real Sector Economics and Forecasting. Textbook. Tashkent. Iqtisod-moliya. -2013. -P. 220-222.

[11] Li Xiaoyu, Xiao Duning, He Xingyuan, et al. Dynamics of typical agricultural landscape and its relationship with water resource in inland Shiyang river watershed, Gansu Province, Northwest China. Environmental Monitoring and Assessment' 2006(36): 325-326.

[12] Mahsudov M.D. Диверсификация землепользования является фактором развития. Monograph. LAP Lambert Academic Publishing, 2019. -P. - 54-57. [10].

[13] Hansson, H., Ferguson, R., Olofsson, C. and Rantamäki-Lahtinenb, L. (2013). Farmers' motives for diversifying their farm business - The influence of family. Journal of Rural Studies, 32: 240-250.

[14] Mahsudov M.D. Land use and management issues in local areas // "'Problems of improving the efficiency of work of modern production and economy of energy-resources" International Scientific and Practical Conference materials. -Andijan, Uzbekistan: - 2018. -P. 717-719.

[15] Mahsudov M.D. Suggestions for land use and management in the regions// "Problems of increasing energy use in agrarian sectors", International Scientific and Technical Conference materials. -Tashkent, Uzbekistan: - 2018. -P. 272-274.

[16] Mahsudov M.D. The importance of diversifying the use of land resources in production // 'Improving Management Practices in Production Enterprises: Problems and Solutions' Republican scientific and technical conference materials. -Ferghana, Uzbekistan: - 2018. -P. 249-251.

[17] Mahsudov M.D. Improving the Methods of Forecasting the Diversification of the Land Fund in theRegion. International Journal of Engineering Management. Vol. 2, No. 4, 2018, pp. 88-92. doi: 10.11648/j.ijem.20180204.12

[18] Materials of separate reports of the State Committee of the Republic of Uzbekistan on Land Resources, Geodesy, Cartography and State Cadastre for 2000-2018.

[19] Md. Salauddin Palash*, Siegfried Bauer. Diversification of Farmland use in Bangladesh: Land Allocation Impacts on Farm Profitability. De Gruyter Open. 2017; 2: 175-177.
[20] Altiev A.S. Liberalization of land relations. "Society and administration" scientific-political, socio-economic, spiritual-historical journal. Tashkent, 2008, №1, Pp. 120-122. (08.00.00, No. 8). 